\title{
Ras-Related Protein Rab-6B
}

National Cancer Institute

\section{Source}

National Cancer Institute. Ras-Related Protein Rab-6B. NCI Thesaurus. Code C158499.

Ras-related protein Rab-6B (208 aa, $\sim 23 \mathrm{kDa}$ ) is encoded by the human RAB6B gene.

This protein is involved in the regulation of retrograde transport. 